\title{
Radiocarbon Chronology and Problems in Its Interpretation for Quaternary Loess Deposits-South Canterbury, New Zealand ${ }^{1}$
}

\author{
E. C. A. Runge, K. M. Goh, AND T. A. RAFter ${ }^{2}$
}

\begin{abstract}
The sequence of events for the loess deposits on the Timaru Downs as indicated by ${ }^{14} \mathrm{C}$ dating of clay-organic complexes, and whole and fractionated peat deposits is as follows: present soil and surficial peat have been forming from present to 9,900 years BP; uppermost loess was deposited between 9,900 and 11,800 years BP; first palesol and buried peat was formed 11,800 to 31,000 or more years $\mathrm{BP}$; and the second loess was deposited $>31,000$ years BP.

The mean residence time (MRT) of clay-organic complexes from the B2 horizon of the modern soil and paleosols was compared to the MRT's of fractionated and unfractionated samples of organic material from stratigraphically related peat deposits. In this study the chronology from whole organic samples was improved by dating fulvic acid, humic acid, and residence (humin) fractions. Humic acid fractions gave consistently older dates than residue fractions. The relative amount of these three fractions provides information about subsequent contamination. Concentrated organic deposits are preferred. However, clay-organic complexes of paleosols can be used to approximate the chronology of events after a correction for age at time of burial if contamination by organic material through leaching during subsequent soil development can be accounted for. The clay-organic complex method may extend ${ }^{14} \mathrm{C}$ dating to paleosol horizons enriched with clay (B2 horizons) but devoid of organic enriched horizons (peat, muck, or $\mathbf{A}$ horizons).
\end{abstract}

Additional Index Words: ${ }^{14} \mathrm{C}$ dating, paleosols, clay-organic complexes, Pleistocence loess deposits.

$\mathrm{T}$

HE MUltiple Loess deposits on the Timaru Downs, New Zealand (Raeside, 1964) were studied and found to contain four or five loess deposits. Each loess deposit is recognized by a soil developed in the upper increment of loess (Runge, Walker, and Howarth, 1973; Tonkin, Runge, and Ives, 1973).

Radiocarbon dating of organic rich horizons has been used by pedologists and geologists for some time. However, only recently problems in dating organic rich soil horizons have been studied. Campbell et al. (1967a, 1967b) applied the ${ }^{14} \mathrm{C}$ dating method to soil organic matter investigations. They determined the mean residence time (MRT) of soil humic fractions and found the residual carbon after alkali extraction to have the oldest, humic acids intermediate, and

\footnotetext{
${ }^{1}$ Contribution from the Dep. of Soil Science, Lincoln College, Univ. of Canterbury, New Zealand, and the Dep. of Agronomy, Univ. of Illinois, Urbana. Supported in part by a Senior Post-Doctoral Fellowship to the senior author while on sabbatic leave from the Univ. of Illinois and by a research grant from the Univ. Grants Committee, New Zealand. Received Dec. 18, 1972. Approved April 30, 1973.

${ }^{2}$ Former Senior Post-Doctoral Fellow, Lincoln College and Prof. of Soils, Univ. of Illinois; Senior Lecturer, Lincoln College; and Director, The Institute of Nuclear Science, DSIR, Lower Hutt, New Zealand, respectively. The authors would like to acknowledge the assistance of Charles Moore, ${ }^{14} \mathrm{C}$ Laboratory, The Institute of Nuclear Science; P. J. Tonkin, Lecturer, Lincoln College; and Margaret Gibbons, Technician, Lincoln College.
}

fulvic acids the youngest MRT for the modern Chernozemic and Podzolic Grey-Wooded soil horizons studied. They also studied several fractions of the humic acids and found the stable calcium humates to be oldest (1400 years) and labile humic acid hydrolysates to be the youngest (25 years) for the Chernozem soil. In this paper MRT is used for the ${ }^{14} \mathrm{C}$ age of fractions and whole samples throughout including literature citations. The carbon in the various fractions is assumed to have undergone or is still undergoing exchange with other carbon fractions or with more recent carbon.

Polach and Costin (1971) analyzed carbon fractions from buried soils in Australia. They found that carbonized wood gave the oldest MRT but that humic acid gave consistently older dates than the residual carbon after alkali extraction. They did not report results for the fulvic acid fraction. Scharpenseel (1971a) also reports data on organic fractions from several modern soils at various depths. The humin fraction (residual carbon after alkali extraction) generally had a younger MRT than the humic acid fraction. Later Scharpenseel (1971b) recommended the use of clay-humus (clay-organic complex) as a suitable material for dating soils formed from loess. He did not, however, present any conclusive evidence to support his proposal. Scharpenseel (1971a) also found that the MRT of soil horizons generally increases with increasing soil depth. Gracanin (1971) and Herrera and Tamers (1971) also report systematic increases in MRT with increasing soil depth.

Ballagh and Runge (1970) used MRT to help understand the genesis of fine clay horizons over limestone. They found the MRT of the clay-organic complex at 116-117 $\mathrm{cm}$, adjacent to the limestone, to be 4,270 years while at $104-105 \mathrm{~cm}$, it was 9,330 years. This decrease in age of 5,060 years with $12 \mathrm{~cm}$ deeper depth is contrary to the findings of Scharpenseel (1971a), Gracanin (1971), and Herrera and Tamers (1971). This large decrease in age is attributed to eluviation of the most recently synthesized clay-organic complex from the overlying A and B horizons and subsequent deposition due to flocculation as the $\mathrm{pH}$ and $\mathrm{Ca}^{2+}$ activity increase abruptly adjacent to the limestone. The clay is moved in suspension by percolating water. Scharpenseel, Pietigard, and Tamers (1968) reported other examples where MRT decreases by a small amount with increasing depth; however, it cannot be determined from data available whether these reversals are also due to abrupt changes in $\mathrm{pH}$ and $\mathrm{Ca}^{2}+$ activity.

\section{EXPERIMENTAL PROCEDURE}

The South Canterbury Brickworks (SCBW) section (Tonkin et al., 1973), which consists of a modern soil and three paleosols developed in loess, was selected for determining the suitability of clay-organic complex method of radiocarbon dating well-drained paleosols that are devoid of organic carbon rich surface horizons. Most all well-drained paleosols lose their 
darkness and most of their carbon from the former A horizon after burial. The loess at Timaru is devoid of calcium carbonate. Consequently there is no soil material having a high $\mathrm{Ca}^{2+}$ activity that would flocculate clay that might move with deeply percolating water as the adjacent younger soil was being developed. Such movement, if it occurs, would contaminate the clayorganic complex of the paleosol with more recent carbon and would result in low MRT. However, the annual rainfall at Timaru is $550 \mathrm{~mm}$ and minimal water is available for deep percolation. A relatively impermeable fragipan horizon (may approach a duripan in some instances) that is part of the modern solum temporarily perches any abnormal amount of excess rainfall and should further reduce deep percolation (Runge et al., 1973).

Since clay-organic complexes are formed continuously (it is assumed that the flux is low but constant per unit time) during soil development, the clay-organic complex from the modern soil was dated to provide an approximate correction factor for the paleosols. This correction is the MRT of the present soil and is the assumed age the clay-organic complex would have if the soil was suddenly buried. The MRT of the present soil is subtracted from the MRT of the paleosol clay-organic complexes to give an approximate age of the buried paleosol. Such a correction assumes that the MRT of the clay-organic complex of each of the paleosols upon burial is approximated by the MRT of the modern soil. Clearly this assumption may not be valid. However, the possibility of obtaining approximate dates from soil clay-organic complexes for paleosols devoid of organic rich surface horizons but having easily identifiable clay enriched horizons may be very rewarding. Also the degree of pedological development may help refine the correction in some instances.

To check the validity of the above reasoning, peat bogs on the Timaru Downs $2.2 \mathrm{~km}$ south of the SCBW section were sampled. The stratigraphy of these bogs and surrounding landscape (Darling sections) are reported elsewhere (Tonkin et al., 1973). The stratigraphy of the Darling no. 5 section, 35.5 $\mathrm{m}$ above mean sea level (MAMSL), is similar to the SCBW section (25.9 MAMSL) except a fourth paleosol developed in the fifth loess is present. The Darling no. 1 section, in the center of a bog, has a modern surficial peat and one buried peat that developed contemporaneously with the modern soil and the first paleosol (Tonkin et al., 1973).

The SCBW section was bulk sampled at $0.47-0.65 \mathrm{~m}$ (modern B2 horizon), $4.10-4.25 \mathrm{~m}$ (first paleosol B2 horizon), $7.75-8.00 \mathrm{~m}$ (top of second paleosol B2 horizon), and 8.10 $8.25 \mathrm{~m}$ (middle of second paleosol B2 horizon). The clay was separated by sedimentation and decantation, flocculated with $\mathrm{NaCl}$, centrifuged, and dried. After drying the clay was ground and used to determine ${ }^{14} \mathrm{C}$ activity and the MRT of the organic carbon.

The Darling no. 1 section was sampled at: (i) the lower increment of the surficial peat; (ii) the interface of the surficial peat and the first loess (sampled from an adjacent bog); (iii) the interface of the first loess and the buried peat; (iv) the middle of the buried peat; (v) the interface of the buried peat and the second loess; (vi) $0.60-0.75 \mathrm{~m}$ below the bottom of the buried peat; and (vii) $1.00-1.10 \mathrm{~m}$ below the bottom of the buried peat. The sample at the interface of the surficial peat and the first loess was sampled from an adjacent bog where the deepest surficial peat $(2.2 \mathrm{~m})$ on the Timaru Downs is known to exist. The surficial peat is $1.25 \mathrm{~m}$ deep at the Darling no. 1 section. A picture of the sharp contact between the surficial peat and the top of loess 1 is given by Fig. 1 . Evidently loess deposition ended abruptly.

Peats were bulk extracted for obtaining humic and fulvic acids, and residue (humin) for radiocarbon dating by using $100 \mathrm{~g}$ of finely-ground peat (passing through 60 -mesh sieves) per 4 liters of $0.5 M \mathrm{NaOH}$ solution. After thorough intermittent stirring for 2 hours, the suspension was allowed to settle over night. It was then centrifuged to obtain the supernatant extract which was immediately acidified with dilute $\mathrm{HCl}$ to separate the humic and fulvic acids. After the removal of the supernatant extract, the residue was extracted four more times

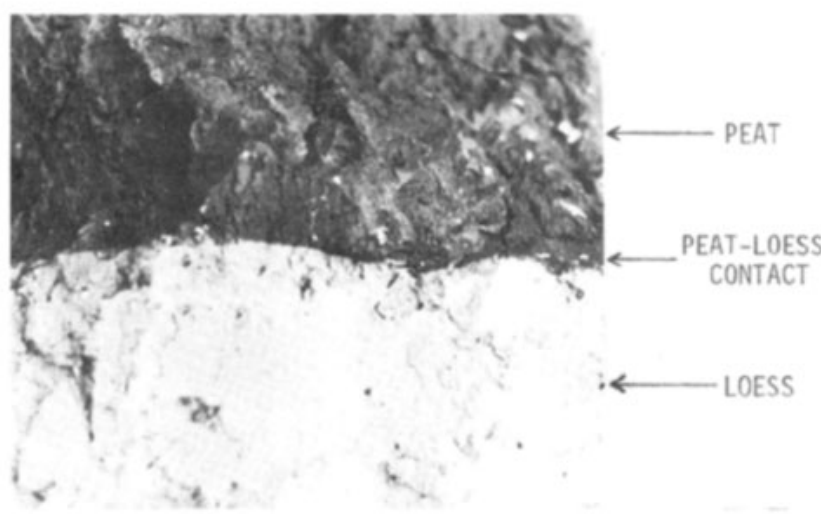

Fig. 1-Contact between top of loess no. 1 and surficial peat at Darling no. 1 section.

with $0.5 \mathrm{M} \mathrm{NaOH}$. Finally, it was acidified to $\mathrm{pH} 1.0$ and dried under forced draught below $70 \mathrm{C}$ together with the humic and fulvic acids recovered in the repeated extractions. After drying all these organic matter fractions were ground to pass through a 60 -mesh sieve before being assayed for ${ }^{14} \mathrm{C}$. The amount of humic and fulvic acid and humin carbon in the peat samples were determined by the method described elsewhere (Kononova, 1966, Goh and Stout, 1972).

All ${ }^{14} \mathrm{C}$ activities and ${ }^{13} \mathrm{C} /{ }^{12} \mathrm{C}$ ratios were determined and MRT assigned by the Institute of Nuclear Sciences, DSIR, Lower Hutt, New Zealand.

\section{RESULTS AND DISCUSSION}

The clay-organic complex from the B2 horizon of the modern soil has a MRT of $3,040 \pm 60$ radiocarbon years. This is similar to the dates obtained by Ballagh and Runge (1970) for clay-organic complexes in soils under development for approximately 14,000 years. If the assumption is made that the MRT of the clay-organic complex of the paleosols was approximately 3,000 years at time of burial, the MRT for each of the paleosols should be reduced by that amount. This assumes that each of the paleosols would have clay-organic complexes of similar age upon burial as the modern soil. The pedological development of the first paleosol is similar but somewhat greater than for the modern soil. Therefore, the 3,000 year correction is a minimal correction. The pedological development of the second paleosol differs from the modern soil (type and position of horizons) but resembles present day profile development that occurs in the higher rainfall areas of Southland, New Zealand. Therefore the relative correction for the second paleosol is difficult to assess but is judged to be similar to the modern soil.

The clay-organic complex MRT of the first and second paleosols was $19,400 \pm 350$ and $21,500 \pm 450$, respectively (Table 1). The corrected MRT is then approximately 16,400 and 18,500 radiocarbon years, respectively (Fig. 2). These clay-organic complex dates are compared to whole and fraction sample dates from the bog sites to evaluate their reliability (Table 1 and Fig. 2).

The clay-organic complex date for the second paleosol is too young when the amount of pedologic weathering of paleosol one and the time necessary for deposition of loess two is considered. Two sources of contamination are suggested: (i) contamination by modern roots of plants growing on the exposed cut and (ii) contamination of more 
Table $1-{ }^{14} \mathrm{C}$ age, sample description, and related data

\begin{tabular}{|c|c|c|c|c|c|c|}
\hline${ }^{14} \mathrm{C}$ no. & $\begin{array}{l}\text { I. N. S. re-- } \\
\text { search no. }{ }^{\dagger}\end{array}$ & Description & $\% \mathbf{c}$ & $\delta^{13} \mathrm{C} \ddagger$ & ${ }^{14} \mathrm{C}$ "Age" 8 & Comments \\
\hline \multicolumn{7}{|c|}{ Unfractionated-Organic Rich Samples } \\
\hline $\mathrm{NZ} * 1258$ & R. 4015-1 & $\begin{array}{l}\text { Surflctal peat in bog adjacent to Darling no. I bog. Depth } \\
2.18-2.19 \mathrm{~m} \text { at the eontact of the surfictal peat and the } \\
\text { first loess. }\end{array}$ & 2.49 & -29.5 & $9,900 \pm 100$ & $\begin{array}{l}\text { This peat sample was taken from the bog where the deepest } \\
\text { surflclal peat }(2.2 \mathrm{~m}) \text { on the Timaru Downs } 1 \mathrm{~s} \text { know to ex- } \\
\text { ist. Sample should date cessation of deposition of loess } 1 \text {. }\end{array}$ \\
\hline NZ 1259 & R. $4015-2$ & $\begin{array}{l}\text { Burled peat from Darling no. } 1 \text { sectlon. Sample taken from } \\
\text { the contact loess } 1 \text { and burled peat. Depth } 5.00-5.02 \mathrm{~m} \\
\text { below the present surface. }\end{array}$ & 0.87 & -28.1 & $12,000 \pm 120$ & $\begin{array}{l}\text { This sample should date the onset of deposition of loess } 1 \text {, } \\
\text { whlch forms the present surface. }\end{array}$ \\
\hline NZ 1260 & R. 4015-3 & $\begin{array}{l}\text { Burled peat from Darllng no. I seetlon, Sample taken from } \\
\text { the contact of burled peat and loess 2. Depth } 5.27-5.30 \mathrm{~m} \\
\text { below the present surface. }\end{array}$ & $1.06^{\circ}$ & -29.2 & $27,200 \pm 600$ & $\begin{array}{l}\text { This sample should date the cessation of deposition of loess } 2 \\
\text { and the onset of soll development when loess no. } 2 \text { was at } \\
\text { the surface. }\end{array}$ \\
\hline NZ 1270 & R. $4015-13$ & $\begin{array}{l}\text { Darkened silt band from Darling no. 1. Sample taken from } \\
6.25-6.3 \mathrm{~m} \text { below the present surface and } 1.00-1.10 \mathrm{~m} \text { be- } \\
\text { low the burled peat. }\end{array}$ & 0.32 & -21.8 & $15,650 \pm 210$ & Loess below buried peat. \\
\hline $\mathrm{NZ} 1271$ & R. 4015-14 & $\begin{array}{l}\text { Darkened sllt band from Darling no. 1. Sample taken from } \\
5.85-6.00 \mathrm{~m} \text { below the present surface and } 0.60-0.75 \mathrm{~m} \text { be- } \\
\text { low burled peat. }\end{array}$ & 0.36 & -27.3 & $17,300 \pm 260$ & Same comment as for R. 4015-13. \\
\hline \multicolumn{7}{|c|}{ Fractlonated-Organic Rlch Samples } \\
\hline NZ 1264 & R. $4015-7$ & Fulvle aelds extracted from surficial peat. & 0.50 & -27.5 & $8,960 \pm 150$ & $\begin{array}{l}\text { Sample was taken from lower increment of surfielal peat at } \\
\text { Darling no. } 1 \text { sectlon from } 1.10-1.23 \text { m below present sur- } \\
\text { face. }\end{array}$ \\
\hline NZ 1266 & R. 4015-9 & Residual carbon from surficlal peat. & 4.11 & -29.0 & $6,720 \pm 80$ & Same comment as for R. 4015-7. \\
\hline NZ 1268 & R.4015-11 & Humlc aeids extracted from surfictal peat. & 22.2 & -28.5 & $9,400 \pm 100$ & Same comment as for $R, 4015-7$ \\
\hline NZ 1265 & R. 4015-8 & Fulvle aclds extracted from burled peat. & 0.23 & -28.7 & $11,800 \pm 190$ & $\begin{array}{l}\text { Sample was taken from tbe burled peat at Darling no. } 1 \mathrm{sec}- \\
\text { tlon from } 5.00-5.25 \mathrm{~m} \text { below present surface. }\end{array}$ \\
\hline NZ 1267 & R. 4015-10 & Residual carbon from burled peat. & 4.2 & -32.1 & $15,450 \pm 200$ & Same comment as for R. 4015-8. \\
\hline NZ 1269 & R. 4015-12 & Hunlc aclds extracted from burled peat, & 19.1 & -29.5 & $\begin{array}{r}31,000+1,100 \\
-\quad 900\end{array}$ & Same comment as for R. 4015-8. \\
\hline \multicolumn{7}{|c|}{ Clay-Organic Samples } \\
\hline NZ 1261 & R. 4015-4 & $\begin{array}{l}\text { South Canterbury Brickworks Section ( } \mathrm{SCBW} \text { ). Sample taken } \\
\text { from } 0.47-0.64 \mathrm{~m} \text { below the present surface. }\end{array}$ & 1.03 & -25.1 & $3,040 \pm 60$ & $\begin{array}{l}\text { Loess no. 1. Th1s is the clay-organic complex from the pre- } \\
\text { sent-day clay enrlched horizon near the surface, B2 horl- } \\
\text { zon. }\end{array}$ \\
\hline NZ 1262 & R. 4015-5 & $\begin{array}{l}\text { SCBW Section. Sample taken from } 4.10-4.25 \mathrm{~m} \text { below the } \\
\text { present gurface. }\end{array}$ & 0.27 & -27.9 & $19,400 \pm 350$ & $\begin{array}{l}\text { Loess no. 2. Thls 1s the clay-organle eomplex from the flrst } \\
\text { paleosol clay encriched horizon, paleo B2 horlzon. }\end{array}$ \\
\hline NZ 1263 & R. 4015-6 & $\begin{array}{l}\text { SCBW Sectlon. Sample taken from } 7.75-8.00 \mathrm{~m} \text { bclow the } \\
\text { present surface. }\end{array}$ & 0.20 & -27.1 & $15,600 \pm 400$ & $\begin{array}{l}\text { Loess no. 3. Thls is the clay-organle complex from the sec- } \\
\text { ond paleosol, clay enriched horizon, paleo B2 horizon. } \\
\text { Sample apparently contamlnated in clay separatlon stage. } \\
\text { Resampled and dated as R. 4015-15. }\end{array}$ \\
\hline NZ 1308 & R. 4015-15 & $\begin{array}{l}\text { SCBW Section, Sample taken from } 8.10-8.25 \mathrm{~m} \text { below the } \\
\text { present gurface. }\end{array}$ & 0.19 & -26.8 & $21,500 \pm 450$ & $\begin{array}{l}\text { Loess no. 3. This ts the clay-organic complex from the sec- } \\
\text { ond paleosol, elay enrlched horlzon, paleo B2 horlzon. }\end{array}$ \\
\hline
\end{tabular}

recently illuviated clay-organic complexes during the development of the first paleosol by percolating water. Since the SCBW section has only recently been exposed, the percolation of water during the development of the first paleosol would seem to be the largest source of contamination.

The dates obtained from whole unfractionated samples at the peat-loess contacts and the darkened silt bands 0.600.75 and $1.00-1.10 \mathrm{~m}$ below the bured peat are also given (Table 1 and Fig. 2). We interpret these MRT as followsthe 9,900 year date approximated when loess deposition stopped and development of the present soil and surficial peat started; the 12,000 year date approximates the time when the deposition of loess one started; and the 27,000 year date approximates when soil development of the first paleosol and the buried peat started. The dates on the darkened silt bands will be discussed later. The whole fraction dates allow us to say: (i) that the present soil has developed from 9,900 radiocarbon years ago to the present time; (ii) that loess one deposition was active for 2,100 years from 12,000 to 9,900 years BP; and (iii) that paleosol one was developed in loess two from 27,000 to 12,000 years BP.

The MRT results for the three fractions of the surficial and buried peats are given in Table 1 and Fig. 2. Depending on the fraction the surficial peat varies in MRT from 6,720 to 9,400 years BP, while the buried peat varies from 11,800 to 31,000 years BP. The maximum age for both peats is given by the humic acid fraction. The residue sample gives the youngest date for the surface peat and an in- termediate date for the buried peat. The fulvic acid date of 11,800 years for the buried peat is only 200 years different and within the error of the whole sample located slightly above it and is used as the date of burial of the buried peat.

The decreasing MRT with increasing depth for the two slightly darkened silt bands below the buried peat is perplexing but has a logical explanation. Our reasoning is as follows. The mobile constituents (those that move with percolating water) present in the buried peat during its development are adsorbed to the inorganic surface of the loess or precipitated by the metal ions in the loess. As the adsorption surface or metal ions become saturated, the mobile constituents (fulvic acid) move to the next deeper depth and become adsorbed. This process continued throughout the formation of the now buried peat. The permeability of the loess is low and consequently the flow of water past an active surface is negligible. Thus, it would seem that any readsorption or dissolution-reprecipitation would be negligible. Also, the amount of biological activity in and below the peat should be low so that once the organic constituents are immobilized, they remain that way.

The amount of carbon present as fulvic acid, humic acid, and residue (humin) in the various samples provides insight into the amount of contamination (Table 2). It is evident from these data that the inversion of ${ }^{14} \mathrm{C}$ age with depth can be accounted for by the amount of fulvic present more than by the amount of humic acid or humin. The production of a younger ${ }^{14} \mathrm{C}$ age with depth was accompa- 


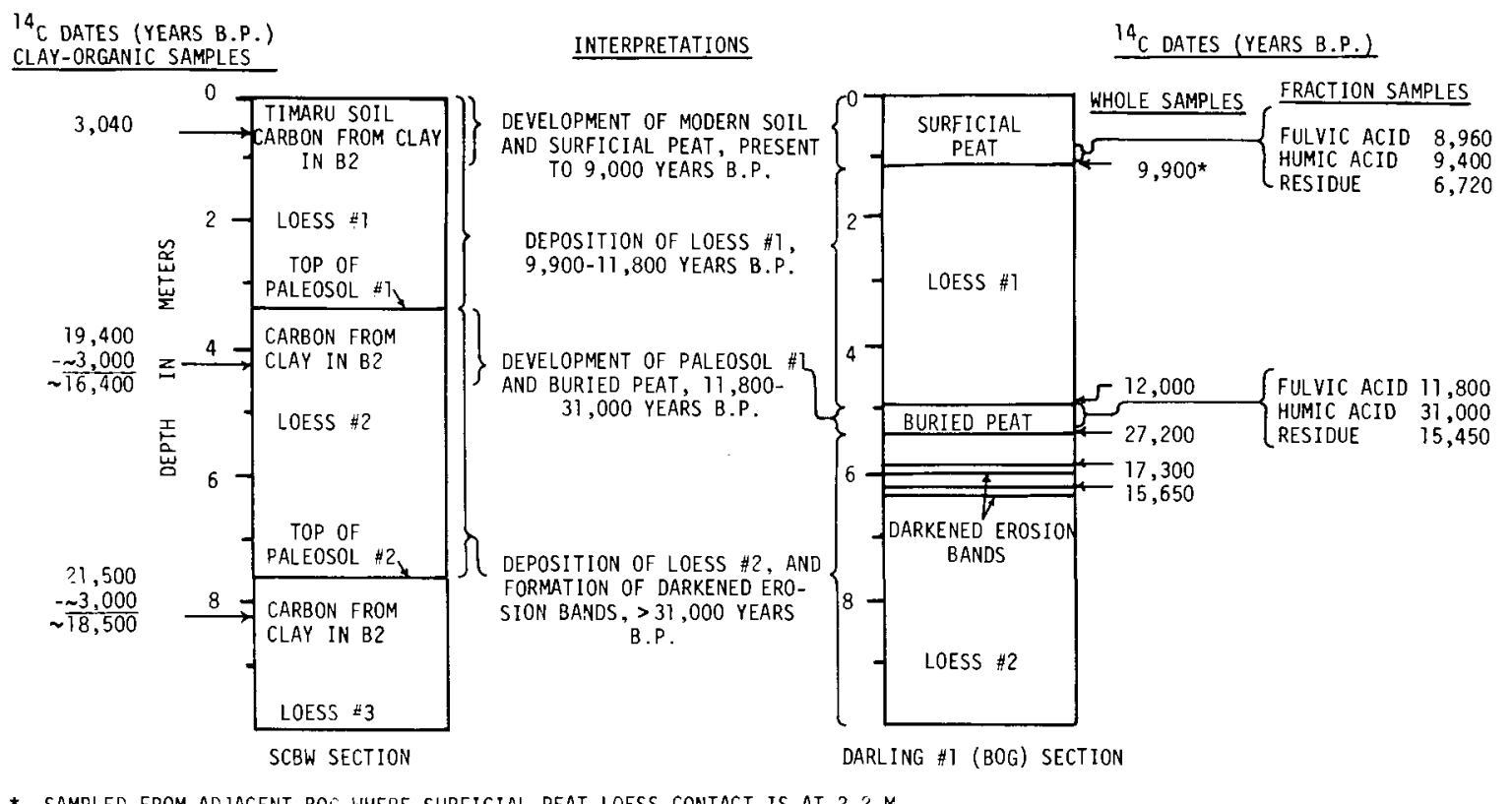

Fig. 2-MRT, position of samples, and interpretation of dates.

nied by an increase in the amount of fulvic acid carbon (e.g. R4015-14 vs. R4015-13, and R4015-5 vs. R4015-6). This suggests that fulvic acids, being water-soluble, and also of relatively younger ${ }^{14} \mathrm{C}$ ages (as discussed earlier) are the main agents of humic contaminants. A similar conclusion was reached earlier in other studies (Goh and Molloy, 1972).

From our data it appears that the humic acid fractions are more useful for dating partially decomposed peat samples than are residue (humin) fractions (many dates in the literature are residue dates). Similar conclusions can be made from the data presented by Polach and Costin (1971) and Scharpenseel (1971a). The difference in MRT of 14,500 radiocarbon years for the humic acid over the residue fraction for the buried peat $(94 \%$ increase over the residue date) is larger than any difference we've seen reported in the literature. This strongly suggests that a larger proportion of the recently formed plant constituents was included in the residue (humin) fraction of the peat than those reported for other soils (Polach and Costin, 1971; Scharpenseel, 1971a). In addition, the method of extraction was exhaustive and a better separation of humic acid and residue could have been achieved.

The interpretation of events after examining the MRT dates for all the samples is the following: the present soil and the surficial peat have been developing from present to 9,900 years $\mathrm{BP}$; loess one was deposited in the interval 9,900 to 11,800 years BP; paleosol one and the buried peat were formed in the interval 11,800 to 31,000 or more years BP; and loess two was deposited more than 31,000 years BP.

\section{CONCLUSIONS}

The clay-organic complex can be used to approximate the age of buried paleosols if contamination can be accounted for (for example, dry climate or presence of solu- ble salts including $\mathrm{CaCO}_{3}$ ). The corrected MRT of 16,400 years for the clay-organic complex of the first paleosol developed in loess two is reasonable considering the soil formed during the interval 11,800 to 31,000 radiocarbon years ago. However, the correct MRT of 18,500 for the second paleosol developed in loess three is not reasonable since it must be older than 31,000 radiocarbon years when all the other dates and stratigraphic relationships are considered. The technical problems of fractionating clayorganic complexes (approximately 1\% C) into fulvic acid, humic acid, and residue (humin) are great but their effect on MRT's may be considerable.

Conclusions and interpretations based on MRT of dispersed organic matter from soil horizons must be reached with caution. For example, the buried peat in our study had MRT's of $11,800,15,450$, and 31,000 years BP based on fulvic acid, residue, and humic acid, respectively. The MRT of the humic acid fraction is $94 \%$ greater than the MRT of the residue fraction. The results of this study suggest that some of the conclusions in the literature based on residue dates may be in error.

Table 2-Radiocarbon dates and the distribution of humic and fulvic acid and humin carbon extracted from soil samples at different depths in the Darling no. 1 and South Canterbury Brickworks Section (SCBW)

\begin{tabular}{|c|c|c|c|c|c|}
\hline $\begin{array}{l}\text { Sample } \\
\text { number }\end{array}$ & $\begin{array}{c}{ }^{14} \text { C age (years } \\
\text { before } 1950 \text { ) }\end{array}$ & $\begin{array}{c}\text { Extractable } \\
\text { carbon }\end{array}$ & $\begin{array}{l}\text { Humic acid } \\
\text { carbon }\end{array}$ & $\begin{array}{l}\text { Fulv1c actd } \\
\text { carbon }\end{array}$ & $\begin{array}{l}\text { Humin } \\
\text { carbor }\end{array}$ \\
\hline & & \multicolumn{4}{|c|}{$-\%$ of total organlc $\mathrm{C}-$} \\
\hline $\begin{array}{l}\text { R. 4015-2 } \\
\text { R. 4015-14 } \\
\text { R. 4015-13 }\end{array}$ & $\begin{array}{l}12,000 \pm 120 \\
17,300 \pm 260 \\
15,650 \pm 210\end{array}$ & $\begin{array}{l}62.3 \\
99.5 \\
80.4\end{array}$ & $\begin{array}{l}18.7 \\
22.3 \\
11.1\end{array}$ & $\begin{array}{l}43.9 \\
77.2 \\
67.7\end{array}$ & $\begin{array}{r}37.7 \\
0.5 \\
19.6\end{array}$ \\
\hline \multicolumn{2}{|c|}{ Level of signiflcance } & $* *$ & $* *$ & $* *$ & \multirow{2}{*}{$\begin{array}{l}* * \\
3.2 \\
5.8\end{array}$} \\
\hline \multicolumn{2}{|c|}{$\begin{array}{l}\text { LSD }(\mathbf{P} \leq 0.05) \\
\text { LSD }(\mathbf{P} \leq 0.01)\end{array}$} & $\begin{array}{l}2.9 \\
5.3\end{array}$ & $\begin{array}{l}2.8 \\
5.1\end{array}$ & $\begin{array}{l}5.1 \\
9.4\end{array}$ & \\
\hline $\begin{array}{l}\text { R. } 4015-4 \\
\text { R. } 4015-5 \\
\text { R. } 4015-6 \\
\text { R. } 4015-15\end{array}$ & $\begin{aligned} 3,040 & \pm 60 \\
19,400 & \pm 350 \\
15,600 & \pm 400 \\
21,500 & \pm 500\end{aligned}$ & $\begin{array}{l}68.3 \\
43.6 \\
58.7 \\
51.2\end{array}$ & $\begin{array}{l}0.0 \\
0.0 \\
0.0 \\
0.0\end{array}$ & $\begin{array}{l}68.3 \\
43.6 \\
58.7 \\
51.2\end{array}$ & $\begin{array}{l}31.7 \\
56.4 \\
41.3 \\
48.8\end{array}$ \\
\hline \multicolumn{2}{|c|}{ Level of significance } & $\cdots$ & ns & 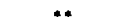 & $\ldots$ \\
\hline \multicolumn{2}{|c|}{$\begin{array}{l}\text { LSD }(\mathbf{P} \leq 0.05) \\
\operatorname{LSD}(\mathbf{P}<0.01)\end{array}$} & $\begin{array}{r}9.8 \\
16.3\end{array}$ & & $\begin{array}{r}9.8 \\
16.3\end{array}$ & $\begin{array}{r}9.3 \\
15.4\end{array}$ \\
\hline
\end{tabular}


Further work on the fractionation of organic matter from organic rich soil horizons should be pursued to determine the best fraction to date. In the interim data reported here plus data of others (Polach and Costin, 1971; Scharpenseel, 1971a) indicate that the humic acid fraction is a better fraction to date than the residue fraction. The clayorganic complex method may extend the usefulness of ${ }^{14} \mathrm{C}$ in dating paleosols having horizons enriched with clay (B2 horizons) but devoid of organic enriched horizons (peat, muck, or A horizons). To guard against errors and help with interpreting dates, anyone using the clay organic method of dating should also determine the amount of fulvic acid, humic acid, and residue in each sample.

\section{LITERATURE CITED}

1. Ballagh, T. M., and E. C. A. Runge. 1970. Clay-rich horizons over limestone-illuvial or residual? Soil Sci. Soc. Amer. Proc. 34:534-536.

2. Campbell, C. A., E. A. Paul, D. A. Rennie, and K. J. McCallum. 1967a. Factors affecting the accuracy of the carbon-dating method in soil humus studies. Soil Sci. 104: 81-85.

3. Campbell, C. A., E. A. Paul, D. A. Rennie, and K. J. McCallum. 1967b. Applicability of the carbon-dating method of analysis to soil humus studies. Soil Sci. 104: 217-224.

4. Goh, K. M., and B. P. J. Molloy. 1972. Reliability of radiocarbon dates from buried charcoals. 8th Int. Radiocarbon Dating Conf. Proc. 2:G29-G45.

5. Goh, K. M., and J. D. Stout. 1972. Radiocarbon enrichment and the turnover of soil organic matter in a chronosequence of soils developed on wind-blown sand in New
Zealand. 8th Int. Radiocarbon Dating Conf. Proc. 2:E67E81.

6. Gracanin, Zlatko. 1971. Age and development of the hummocky meadow (Buckelwiese) in the Lechtaler Alps (Austria). p. 117-127. In Dan H. Yaalon (ed.) Paleopedology. Int. Soc. Soil Sci. and Israel Univ. Press, Jerusalem.

7. Herrera, Rafael, and M. A. Tamers. 1971. Radiocarbon dating of tropical soil associations in Venezuela. p. 109 115. In Dan H. Yaalon (ed.) Paleopedology. Int. Soc. Soil Sci. and Israel Univ. Press, Jerusalem.

8. Kononova, M. M. 1966. Soil organic matter. Pergamon Press, New York, 544 p.

9. Polach, H. A., and A. B. Costin. 1971. Validity of soil organic matter radiocarbon dating: Buried soils in Snowy Mountains, Southeastern Australia as example. p. 89-96. In Dan H. Yaalon (ed.) Paleopedology. Int. Soc. Soil Sci. and Israel Univ. Press, Jerusalem.

10. Raeside, J. D. 1964. Loess deposits of the South Island, New Zealand, and soils formed on them. N.Z. J. Geol. Geophys. 7:811-38.

11. Runge, E. C. A., T. W. Walker and D. T. Howarth. 1973. A study of late Pleistocene loess deposits, South Canterbury, New Zealand. Part I. Forms and amounts of phosphorus compared with other techniques for identifying paleosols. Accepted for publication in Quaternary Research.

12. Scharpenseel, H. W. 1971a. Radiocarbon dating of soilsproblems, troubles, hopes. p. 77-88. In Dan $\mathrm{H}$. Yaalon Paleopedology. Int. Soc. Soil Sci. and Israel Univ. Press, Jerusalem.

13. Scharpenseel, H. W. 1971b. Radiocarbon dating of soils. Soviet Soil Sci. 3 (1):76-83.

14. Scharpenseel, H. W., F. Pietigard, and M. A. Tamers. 1968. Bonn radiocarbon measurements. Radiocarbon 10: 8-28.

15. Tonkin, P. J., E. C. A. Runge, and D. W. Ives. 1973. A study of late Pleistocene loess deposits, South Canterbury, New Zealand. Part II. Paleosols and their stratigraphic implications. Accepted for publication in Quaternary Research. 